DOI:10.17951/h.2017.51.2.29

\begin{tabular}{lcl}
\hline \multicolumn{3}{c}{ A N N A L E S } \\
UNIVERSITATIS MARIAE CURIE-SKŁODOWSKA \\
LUBLIN - POLONIA \\
VOL. LI, 2 & SECTIOH H \\
\hline
\end{tabular}

University of Gdańsk, Faculty of Management, Chair of Marketing

SYLWIA BADOWSKA

sylwia.badowska@ug.edu.pl

\title{
Social Influence and a Process of Acceptance and Use of a Technological Product by the Elderly Consumers
}

Wpływ społeczny a proces akceptacji i użytkowania dobra technologicznego przez konsumentów-seniorów

Key words: social influence; the elderly consumers; process of acceptance and use of technology; UTAUT

Słowa kluczowe: wpływ społeczny; konsument-senior; proces akceptacji i użytkowania technologii; UTAUT

JEL codes: M31; D10; O33

\section{Introduction}

Aging and technological development are global trends and, parallelly, both are becoming a challenge in the field of contemporary marketing. This is due to the fact that technological development has become permanent, and significantly influences today's buyers who as a global population are getting older. Nevertheless, the lacuna of specificity of the elderly consumers behaviour in their processes of acceptance and use of technology products (PAAUTP) exists in the literature. The research sheds light on the issue of technology acceptance by the elderly people in Poland where a gap of present knowledge exists in this field. One of the key moderators of consumer behaviour is social influence (SI). There are some evidences that SI is a critical factor in the PAAUTP. In the context of SI the question arises whether the elderly people perceive others in their circle to have an impact on their purchasing decisions in the aspect of technological products? The aim of this article is to iden- 
tify and evaluate the elderly people's perception of the social influence impact in the process of acceptance and use of the technological product. To verify the goals, the original research on the elderly in Pomeranian Voivodeship, conducted at the turn of 2014-2015 was used, and smartphone as an object of the study was chosen.

\section{The elderly and social influence}

The UN [2015] forecasts that globally the number of people at the age of $60+$ is expected to more than double by 2050 and more than triple by 2100 . Aging process will be particularly intense in well-developed countries [UN, 2015]. This problem is more vital in Poland. In 2035, the elderly will constitute $31.3 \%$ of the society while in 2050 more than $40 \%$ [CSOP, 2014]. That year the Polish population will be among the oldest societies of the world with an average age of citizens of 51.2 [UN, 2015]. According to the CSOP [2016], in 2011, in Poland there were 5.6 million households with people at the age of $60+$, which accounted for $41.5 \%$ of all the households. In Poland, single-person households are more often run by the elderly individuals living alone in comparison with younger ones, and the share of these households reached 40\% [CSOP, 2016]. According to SHARE [2014], only 4.9\% of the Polish elderly are still running professional activities after retirement. Much more professionally active people at the age of 60+ appear in the age groups of 60-64 and 65-69, 31.7\% and $14 \%$, respectively. The share drops significantly for the mature and older elderly [Czapiński and Błędowski 2014].

Howard and Sheth [1969] suggested that commercial and social stimuli inputs promote the action of individuals regarding consumer choices or purchase results. SI is defined as "the degree of impact on the interaction between people in a social network" [Rice and Aydin 1991, pp. 219-244]. SI refers to the way other people affect one's beliefs, feelings and behaviour [Foon and Fah 2011, pp. 161-167]. Social aspects affect the formation of values that influence users' behaviour [DeMooij 2003]. Venkatesh et al. [2008, pp. 483-502] pointed out that the role of SI, especially in the form of social networks of various forms ranging from friendship to hindrance, should be studied as they may play a critical role in determining behaviour directly or by operating through behavioural expectation. Venkatesh et al. [2003, pp. 425-478] reinserted and validated social influences as a significant predictor of intentions in the original model of the unified theory of acceptance and use of technology [UTAUT]. The predictor was revalidated as well in the revised UTAUT2 model and SI in the consumer context is "the extent to which consumers perceive that important others (e.g. family and friends) believe they should use a particular technology" [Venkatesh et al. 2012, pp. 157-178]. Slade et al. [2015, pp. 860-873] interpreted it that individuals tend to consult their social network about new technologies and can be influenced by perceived social pressure of important others. SI has an impact on individual behaviour through three mechanisms: compliance, internalization, 
and identification [Venkatesh and Davies 2000, pp. 186-204]. The intention to buy a smartphone is based on an individual's attitude towards the brand, influence of social norms and other people's expectations [Bojei and Hoo 2010, pp. 289-294]. A loss of social contacts becomes one of the factors behind limitations in the old-age decision-making which means that older people may not receive new information that could be used in decisions [Phillips and Sternthal 1977, pp. 444-457]. SI depends upon social contact and this depends on the survival of friends and relatives, and on membership of groups based on such factors as education, neighbourhood, work, friendship and family [East et al. 2014, pp. 786-801].

\section{Research methodology}

The research aim is to identify and evaluate the elderly people's perception of SI in the process of acceptance and use of the technological product (PAAUTP). The problem is to find the answer to the following question: whether the elderly people perceive others in their circle to have an impact on their purchasing decisions in the aspect of technological products, and then, what is the intensity of this perception? The term "the elderly consumer" is defined as an individual at the age of 60+. The study subject concerns the evaluation of the elderly consumers' perception in the following aspects:

- opinions of people important to the elderly in terms of the use of the product;

- beliefs of people influencing the elderly behaviour in terms of the use of the product;

- preferences of people esteemed and valued by the elderly in terms of use of the product.

The constructs were measured on a five-point Likert scale ranging from 1 "strongly disagree", to 5 - "strongly agree". For targeting the elderly smartphone users, the PAPI technique was used. The questionnaire for the Polish elderly was adapted from the Venkatesh et al.'s study [2003] and pre-tested in a pilot. The proper survey was conducted at the turn of 2014-2015. To secure the efficient number of the respondents, the survey was conducted among the participants of 7 Third Age Universities (TAU) ${ }^{1}$ in Pomeranian Voivodeship. Over 720 questionnaires were distributed and, finally, this effort resulted in 104 respondents of the elderly users of the smartphone. Table 1 presents the sample characteristics.

1 TAU at the University of Gdańsk with branch in Pruszcz Gdański, Pelplin, Kościerzyna; TAU in Gdynia at the Elderly Active Center; TAU in Sopot, TAU in Malbork. 
Pobrane z czasopisma Annales H - Oeconomia http://oeconomia.annales.umcs.pl

Data: 26/04/2023 17:23:21

SYLWIA BADOWSKA

Table 1. Sample characteristics $(\mathrm{n}=104)$

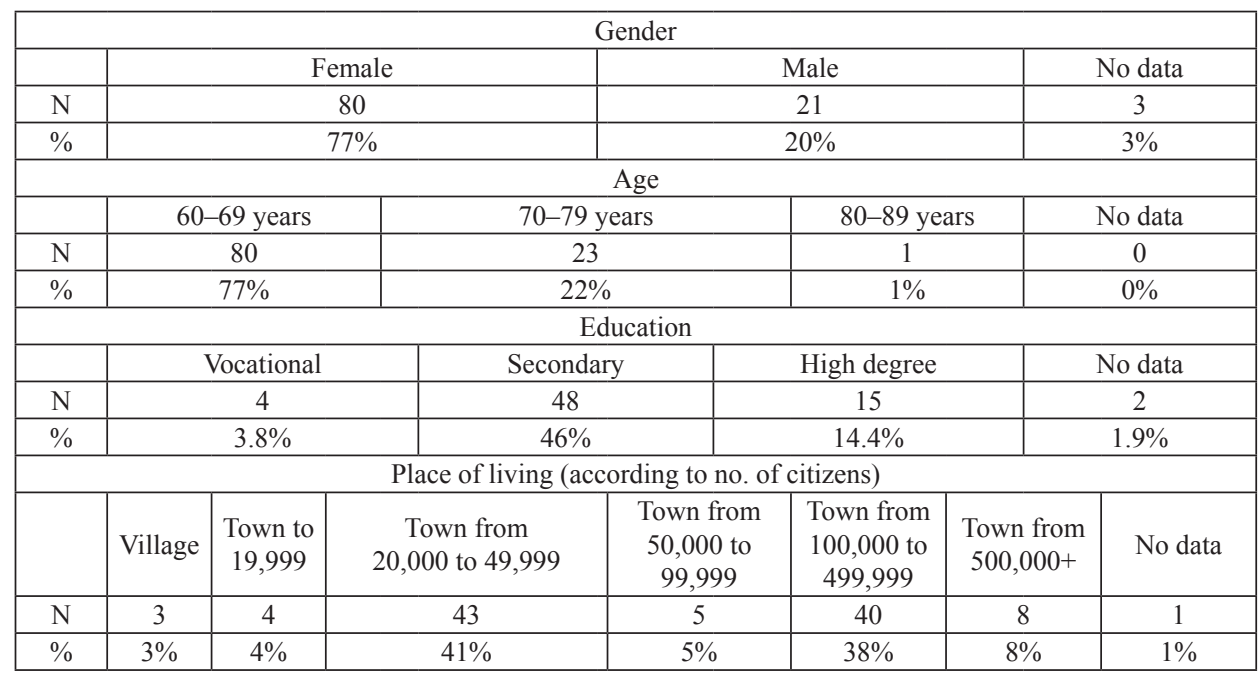

Source: Author's own study based on the original research (2014-2015).

\section{Research results}

The first aspect of SI on the elderly consumers in the PAAUTP was to determine the elderly's perception concerning opinions of people important to the elderly in terms of the use of the smartphone. For the statement: "the people who are important to me, think I should use a smartphone", $12 \%$ of the elderly consumers expressed overwhelming positive feedback. The next $31 \%$ of the respondents indicated that they just agreed with the statement, but with a lower level of conviction. Another $20 \%$ of the elderly neither agreed with the opinion, nor disagreed. Furthermore, $5 \%$ of the respondents indicated that they disagreed that people who are important to them, believe that they should use the smartphone. The remaining 3\% of the respondents expressed the strongly negative opinion. The final $30 \%$ of the elderly did not give any reply to the statement. Figure 1 shows the results.

In conclusion, $43 \%$ of the elderly consumers are convinced that the people who are important to them, think that the elderly should use the smartphone. A completely different opinion was expressed by $8 \%$ of the consumers at the age of $60+$.

The second aspect of SI on the elderly consumers in the PAAUTP was to define the elderly consumers' perception of the beliefs of people influencing the elderly behaviour in terms of the use of the smartphone. The results indicate that $9 \%$ of the elderly consumers strongly agreed that the people who influence their behaviour think they should use the smartphone. The next $30 \%$ of the respondents also confirmed the positive opinion, however, with a lower level of conviction. Another $20 \%$ of the elderly neither agreed nor disagreed with the opinion. Furthermore, only $7 \%$ of the 


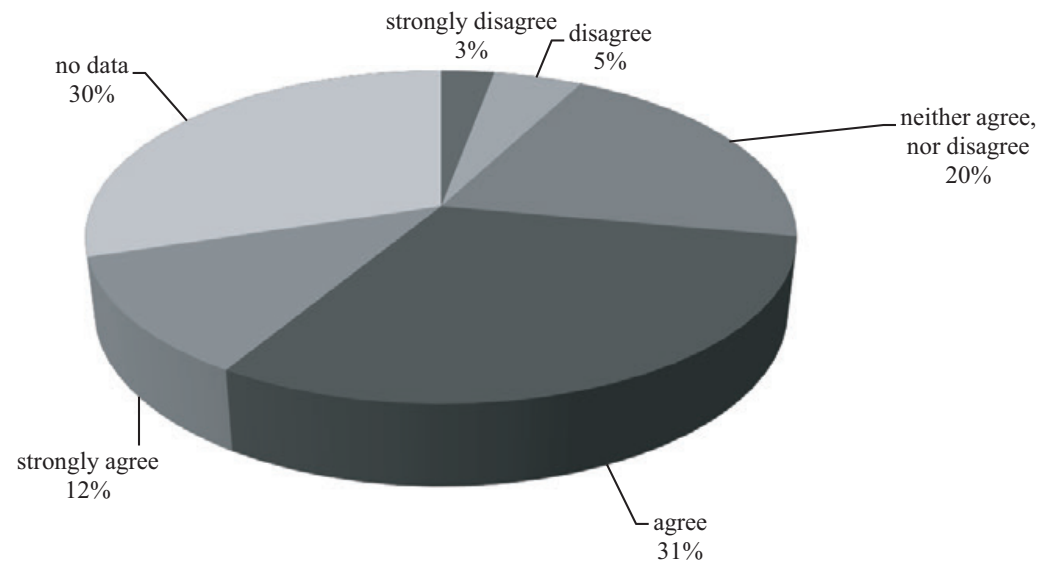

Figure 1. Evaluation of the elderly consumers' perception of the opinions of people important to them in terms of use of the smartphone

Source: Author's own study based on the original research (2014-2015).

respondents pointed out that the people who influence their behaviour do not think that the elderly should use the smartphone. The next $4 \%$ of the consumers strongly disagreed with the opinion. Finally, $31 \%$ of the respondents did not give any answers. Figure 2 shows the results.

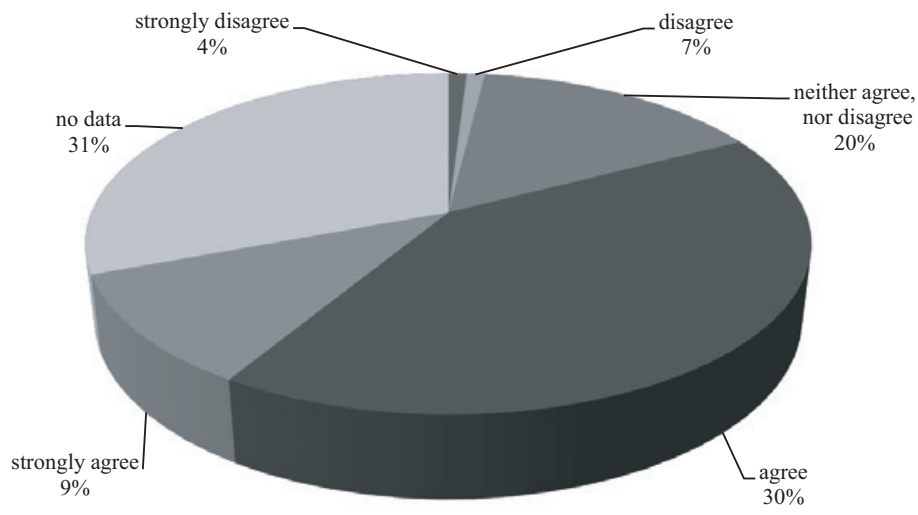

Figure 2. Evaluation of the elderly consumers' perception of beliefs of people influencing the elderly behaviour in terms of use of the smartphone

Source: Author's own study based on the original research (2014-2015).

Concluding, $39 \%$ of the elderly consumers expressed the belief that the people who influence their behaviour, think the elderly should use the smartphone. The contrary oponion was presented by $11 \%$ of the consumers at the age of $60+$. 
The third aspect of SI on the elderly consumers in the PAAUTP was to estimate the elderly consumers' perception of the preferences of the people esteemed and valued by the elderly in terms of use of the smartphone. Based on the outcomes, $8 \%$ of the respondents felt strongly that the people whose opinions they value and esteem prefer the elderly to use the smartphone. The next $26 \%$ of the respondents also expressed the positive opinion, albeit with a lesser level of conviction. Another $20 \%$ of the elderly neither agreed nor disagreed with the statement. Furthermore, $11 \%$ of the respondents disagreed with the statement and the final 3\% strongly disagreed. Lastly, $33 \%$ of the respondents did not give any answers. Figure 3 shows the results.

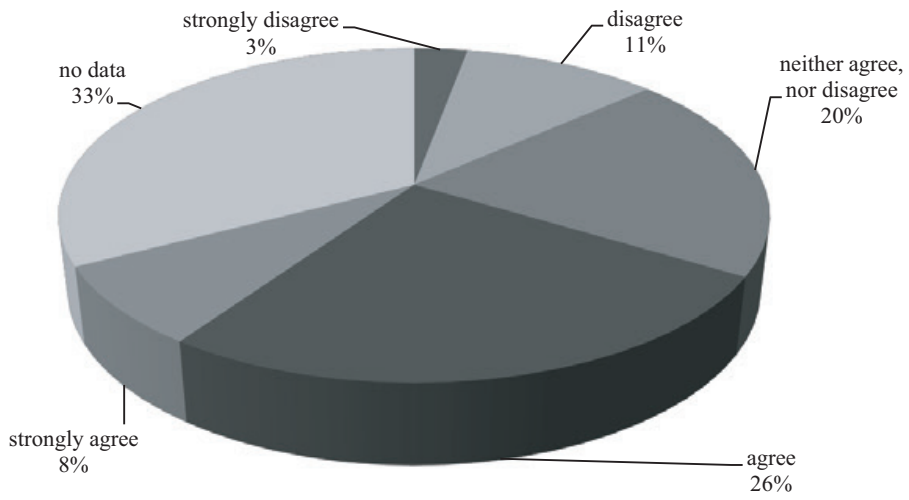

Figure 3. Evaluation of the elderly consumers' perception of preferences of people esteemed and valued by elderly in terms of use of the smartphone

Source: Author's own study based on the original research (2014-2015).

Summing up, 34\% of the elderly consumers are convinced that the people whose opinions they value and esteem think the elderly should use the smartphone. Then, $14 \%$ of the consumers at the age of $60+$ disagree with such a view.

\section{Conclusions}

Based on the literature review, SI is defined as a particularly important factor moderating consumer behaviour and affecting the decision-making process of buyers. It is associated with human relationships and shapes the beliefs of individuals about the phenomena in the close or distant surrounding. It is a measure of other people's influence on conscious or unconscious choice pattern of consumers. Among interfering entities on the consumer decision-making process may be an individual or a group of people associated with family circles and relatives and/or acquaintances the consumers have contact with during their professional activities. All the people around can impact and exert pressure on shopping preferences. SI has been 
applied in the PAAUTP as well. It is described as the degree to which a consumer feels the pressure to use a particular technology product as a result of the opinions of others. Particularly, of those who are especially important to the decision makers. SI is also a substantial element in the PAAUTP by the elderly consumers. In particular, for demographics reasons the role of the elderly consumers is gradually increasing on the market. What is more, technological goods and services are object of interest and acquisition of individuals at the age of $60+$. This supposition is confirmed by the obtained empirical results. The study outcomes indicate that $43 \%$ of the tested elderly pointed out that the people who are important to them, believe that they, as the elderly, should use the smartphone. This suggests that the people from the the elderly's circles may have been using this type of product, got to known its advantages and then they feel the satisfaction of smartfon use. Thus, they would like the tested elderly to enjoy the benefits of the technological product. A large group of the elderly express the feeling of pressure to begin using this type of smart technology. These results correspond quite well with the next research outcomes. For example, $39 \%$ of the elderly expressed the belief that the people who influence their behaviour think the elderly should use the smartphone. Therefore, the elderly consumers who are under the influence of other people recognize the impact of these people on their behaviour in terms of using the smart technology. On the other hand, only one out of three elderly individuals is convinced that the people whose opinions they respect and appreciate prefer that they should use the product. While $14 \%$ of the elderly consumers perceive it differently. In the case of the people who are important to the elderly in their daily life, they do not impact on the studied Polish elderly population so significantly, and the SI is not as intense as it is highlighted in the literature.

The reasons for such outcomes may be the result of several parallel phenomena. In Poland, an important group of the elderly people live in 1-2 person households. Their children have left home and do not live together with already older parents. Therefore, the elderly people remain pretty alone in making consumer decisions. It does not mean that they are completely self-reliant and independent in their consumer choices. The family ties exist, but contacts with adult children may be weaker and weaker. Thus, the children's influence seems to be limited on the decision-making process. Furthermore, the Polish elderly finish their professional activities pretty quickly. Thereby, the elderly naturally are reducing their ongoing contacts with others, including young more technologically advanced generations and their retirement cuts off the possibility to get acquainted with new technologies. Thus, the aggregation of these phenomena possibly contributes to a lower level of SI in the PAAUTP by the tested elderly.

Finally, referring to the aim of this study, it should be highlighted that the results confirm the fact that the tested elderly consumers perceive third parties' SI on the process of their acceptance and use of the smartphone. However, SI can be described as average. This may indicate that the tested elderly consumer's decision-making 
process, in terms of the acceptance and use of technology, is more independent than dependent. Despite the fact that the tested elderly feel the pressure, their decisions are not only a result of SI.

\section{Bibliography}

Bojei, J., Hoo, W.C., Factors Influencing Repurchase Intention of Smartphones, "Journal of Marketing Research", vol. 4, no. 12, 2010, pp. 1-12.

Central Statistical Office of Poland (2014), Prognoza ludności na lata 2014-2050, http://stat.gov.pl/ (access: 17.02.2017).

Central Statistical Office of Poland (2016), Ludność $w$ wieku 60+. Struktura demograficzna i zdrowie, http://stat.gov.pl (access: 17.02.2017).

Czapiński, J., Błędowski, P., Aktywność społeczna osób starszych w kontekscie percepcji Polaków. Diagnoza społeczna 2013. Raport tematyczny, MPiPS, CRZL, 2014, http://www.diagnoza.com/pliki/ raporty_tematyczne/Aktywnosc_spoleczna_osob_starszych.pdf (access: 17.02.2017).

DeMooij, M., Consumer Behavior and Culture: Consequences for Global Marketing and Advertising, Sage Thousand Oaks, CA 2003.

East, R., Uncles, M.D., Lomax, W., Hear Nothing, Do Nothing: The Role of Word of Mouth in the Decision-Making of Older Consumers, "Journal of Marketing Management", vol. 30, no. 7-8, 2014, pp. 786-801.

Foon, Y.S., Fah, B.C.Y., Internet Banking Adoption in Kuala Lumpur: An Application of UTAUT Model, "International Journal of Business and Management", vol. 6, no. 4, 2011, pp. 161-167.

Howard, J., Sheth, J., The Theory of Buyer Behavior, John Wiley, New York 1969.

Phillips, L.W., Sternthal, B., Age Differences in Information Processing: A Perspective on the Aged Consumer, "Journal of Marketing Research", vol. 14, no. 4, 1977, pp. 444-457.

Rice, R.E., Aydin, C., Attitudes Toward New Organizational Technology: Network Proximity as a Mechanism for Social Information Processing, "Administrative Science Quarterly", vol. 36, no. 2, 1991, pp. 219-244.

SHARE - Survey of Health, Ageing and Retirement in Europe. Wave 2, http:/www.share-project.org/ home0/wave-2.html (access: 17.02.2017).

Slade, E.L., Dwivedi, Y.K., Piercy, N.C., Williams, M.D., Modeling Consumers'Adoption Intentions of Remote Mobile Payments in the United Kingdom: Extending UTAUT with Innovativeness, Risk, and Trust, "Psychology \& Marketing", vol. 32, no. 8, 2015 (August), pp. 860-873.

United Nations (2015), World Population Prospects: The 2015 Revision, https://esa.un.org/unpd/wpp/ (access: 17.02.2017).

Venkatesh, V., Brown, S.A., Maruping, L.M., Bala, H., Predicting Different Conceptualizations of System Use: The Competing Roles of Behavioral Intention, Facilitating Conditions, and Behavioral Expectation, "MIS Quarterly", vol. 32, no. 3, 2008, pp. 483-502.

Venkatesh, V., Morris, M.G., Davis, G.B., Davis, F.D., User Acceptance of Information Technology: Towards a Unified View, "MIS Quarterly", vol. 27, no. 3, 2003, pp. 425-478.

Venkatesh, V., Thong, J.Y.L., Xu, X., Consumer Acceptance and Use of Information Technology: Extending the Unified Theory of Acceptance and Use of Technology, "MIS Quarterly", vol. 36, no. 1, 2012 (March), pp. 157-178.

Venkatesh, V., Davis, F., A Theoretical Extension of the Technology Acceptance Model: Four Longitudinal Field Studies, "Management Science”, vol. 46 no. 2, 2000, pp. 186-204. 


\section{Social Influence and a Process of Acceptance and Use of a Technological Product by the Elderly Consumers}

The aim of this article was to present the results of the original research on social influence and its impact on the elderly consumers in the acceptance and use of the technological product. To verify the objective of the research conducted among the elderly consumers at the turn of 2014-2015, the PAPI technique was employed. The results indicate the elderly people perceive the presence of social influence in the process of acceptance and use of the smartphone. However, the impact is limited in this population. This suggests that the tested elderly consumers are guided by their own convictions accepting and using technological products and/or other factors moderate this process parallelly.

\section{Wpływ społeczny a proces akceptacji i użytkowania dobra technologicznego przez konsumentów-seniorów}

Celem artykułu było zaprezentowanie wyników badań własnych dotyczących wpływu społecznego i jego oddziaływania na konsumentów-seniorów w procesie akceptacji i użytkowania dóbr technologicznych. Do weryfikacji celu posłużono się badaniami własnymi przeprowadzonymi wśród konsumentów-seniorów w latach 2014-2015 przy wykorzystaniu techniki PAPI. Wyniki wskazują na postrzeganie przez badanych seniorów występowania wpływu społecznego w procesie akceptacji i użytkowania telefonu komórkowego czy smartfonu. Jednakże wpływ ten jest ograniczony w badanej populacji. Sugeruje to, iż badani konsumenci-seniorzy w ocenianym procesie kierują się własnymi przekonaniami, akceptując i użytkując produkty technologiczne i/lub inne czynniki, równolegle moderujące ten proces. 